\title{
Smith-Lemli-Opitz syndrome: Clinical and biochemical findings in Brazilian patients
}

\author{
Fernanda B. Scalco ${ }^{1}$, Paulo A. Otto ${ }^{2}$, Iguatemy L. Brunetti ${ }^{3}$, Vania M.Cruzes ${ }^{3}$ and Danilo Moretti-Ferreira ${ }^{1}$ \\ ${ }^{1}$ Serviço de Aconselhamento Genético, Universidade Estadual Paulista - UNESP, Botucatu, SP, Brazil. \\ ${ }^{2}$ Departamento de Genética e Biologia Evolutiva, Instituto de Biociências, Universidade de São Paulo, \\ São Paulo, SP, Brazil. \\ ${ }^{3}$ Departamento de Análises Clínicas, Universidade Estadual Paulista - UNESP, Araraquara, SP, Brazil.
}

\begin{abstract}
Smith-Lemli-Opitz syndrome (SLOS) or RSH syndrome comprises multiple congenital anomalies and mental retardation. The underlying defect is a deficiency in the activity of $\Delta^{7}$-sterol reductase, which decreases cholesterol and increases 7-dehydrocholesterol (7-DHC) levels. Our aim was to identify and evaluate the frequency of SLOS manifestations in a group of Brazilian patients. Based on our own data and those reported previously, we present a simple method that allows the estimation of probabilities favoring the diagnosis of SLOS. We evaluated 30 patients clinically and determined their plasma levels of cholesterol and 7-dehydrocholesterol. In 11 patients, the diagnosis was confirmed by ultraviolet spectrophotometry (UV). Of 19 patients with normal laboratory results, 17 showed a high probability favoring the diagnosis of SLOS. The most significant signs and symptoms observed in over $2 / 3$ of the biochemically confirmed cases were mental retardation (10/11), delayed neuropsychomotor development (10/11), syndactyly of $2^{\text {nd }} / 3^{\text {rd }}$ toes $(10 / 11)$, and craniofacial anomalies including microcephaly $(11 / 11)$, incompletely rotated ears (8/11), palpebral ptosis (10/11), anteverted nostrils (10/11), and micrognathia (9/11). Genital anomalies were found in all male patients $(6 / 6)$.
\end{abstract}

Key words: Smith-Lemli-Opitz syndrome, cholesterol metabolism, 7-dehydrocholesterol.

Received: August 16, 2005; Accepted: April 24, 2006.

\section{Introduction}

Smith-Lemli-Opitz (SLOS) or RSH syndrome (MIM 270400) comprises multiple congenital anomalies, mental retardation and an autosomal recessive inborn error of cholesterol metabolism. SLOS is caused by mutations in the gene DHCR7 (Wassif et al., 1998; Fitzky et al., 1998; Moebius et al., 1998; Waterham et al., 1998) which encodes $3 \beta$-hydroxysterol- $\Delta^{7}$-reductase ( $\Delta^{7}$-sterol reductase), an enzyme that catalyzes the conversion of 7-dehydrocholesterol (7-DHC) to cholesterol (Irons et al., 1993; Tint et al., 1994; Shefer et al., 1995). Over 100 different mutations of DHCR7 have been identified in SLOS, all leading to low tissue cholesterol and accumulation of precursor 7-DHC (Yu et al., 2000; Witsch-Baumgartner et al., 2000; Evans et al., 2001; Correa-Cerro and Porter, 2005; Scalco et al., 2005).

The incidence of SLOS is not known accurately; estimates range from 1:10,000 to 1:60,000 (Lowry and Yong,

Send correspondence to Danilo Moretti-Ferreira. Serviço de Aconselhamento Genético,Caixa Postal 529, 18618-000 Botucatu, SP, Brasil. E-mail: sag@fmb.unesp.br.
1980; Ryan et al., 1998; Kelley, 2000; Kelley and Hennekan, 2000; Nowaczyck et al., 2001). This variation may be due to different criteria used in the evaluation of patients.

The clinical manifestations most frequently reported in SLOS include craniofacial anomalies, mental retardation, syndactyly of the second and third toes, and genital malformations in males. Facial anomalies are typical and comprise microcephaly, narrow frontal area, epicanthic folds, ptosis, short nose, broad nasal bridge, anteverted nostrils, micrognathia, and posteriorly angulated or low-set ears. Strabismus, cataract, high-arched or cleft palate, and short neck are also common. Limb defects include postaxial polydactyly of feet and syndactyly of the second and third toes. Genital anomalies (cryptorchidism, hypospadias) are reported in males. Other findings include: delayed global developmental progress with hypotonia and neuropsychomotor disturbances; pyloric stenosis; infection susceptibility during infancy; and various cardiac, renal, and pulmonary anomalies (Curry et al., 1987; Guzzeta et al., 1996; Cunnif et al., 1997; Ryan et al., 1998; KrajewskaWalasek et al., 1999; Nowaczyk and Waye, 2001; Haas and Kelley, 2001). 
The clinical diagnosis of SLOS remains problematic because signs and symptoms presented by affected individuals range from minor anomalies associated with behavioral and learning disabilities to severe malformations and mental retardation, or even neonatal death (Porter, 2000). Biochemical analyses of cholesterol and 7-dehydrocholesterol levels are fundamental to establish a diagnosis of SLOS.

The purpose of the present work was to identify the most common and important findings in SLOS, to compare our data with those of the literature and thus further to delineate the classical SLOS phenotype. In addition, the frequency of the diverse signs and symptoms was used to determine probability figures favoring the diagnosis of SLOS in patients exhibiting negative biochemical results, in order to help the differential diagnosis of SLOS.

\section{Patients and Methods}

\section{Patients}

The study group included 30 patients $(21 \mathrm{M}, 9 \mathrm{~F})$ with findings consistent with SLOS, who were clinically and biochemically evaluated from 2000 through 2002.

The study protocol was approved by both local and national committees of ethics, and informed parental consent was obtained in each case. To standardize clinical ascertainment and anamnestic procedures, the patients were evaluated according to the same protocol.
Figure 1 shows the facial appearance of all 11 patients whose diagnosis was confirmed biochemically.

\section{Biochemical tests}

\section{Cholesterol analysis}

Total plasma cholesterol was determined by an enzymatic colorimetric method (Kit Sera-Pak ${ }^{\circledR}$ Cholesterol, fast color, Bayer ${ }^{\mathbb{B}}$ ) and auto-analyser RAX Bayer, as described by Allain et al. (1974).

\section{7-DHC analysis}

7-DHC was determined by UV spectrophotometry. For this purpose, $200 \mu \mathrm{L}$ of plasma were transferred to glass tubes and vortexed for $10 \mathrm{~s}$ after addition of $200 \mu \mathrm{L}$ of ethanol. Subsequently, $1 \mathrm{~mL}$ of $\mathrm{n}$-hexane was added and the mixture vortexed for another $20 \mathrm{~s}$. After centrifugation at $400 \mathrm{~g}$ for $1 \mathrm{~min}$, the clear $\mathrm{n}$-hexane layer was collected in a $1 \mathrm{~mL}$ quartz cuvet and used for UV measurement. The samples were scanned using a n-hexane blank in the reference beam, and absorption maxima at 271, 282 and $234 \mathrm{~nm}$ were used for detection of 7-DHC in plasma samples; for quantitative analysis, absorption maxima at 234 and $282 \mathrm{~nm}$ were used, as proposed by Honda et al. (1997).

\section{Statistical analysis}

Table 1 shows the frequencies of SLOS findings in our group of 11 confirmed patients and in cases from the lit-

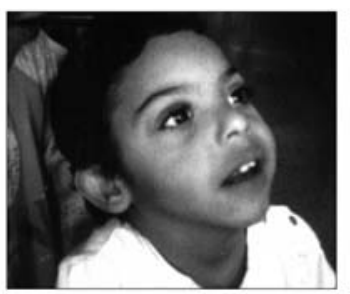

A



E

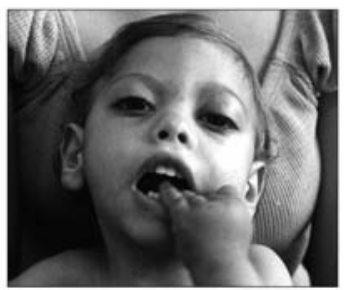

B

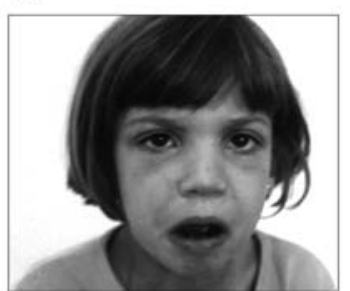

F

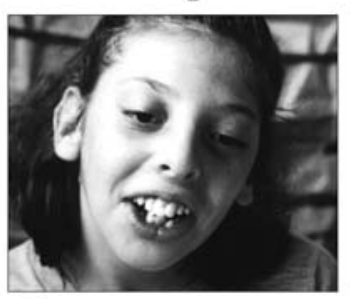

I

J



C

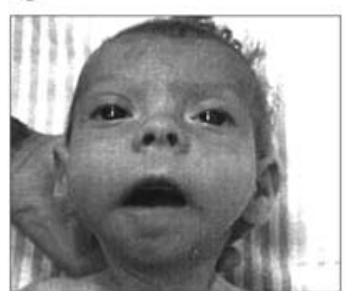

G

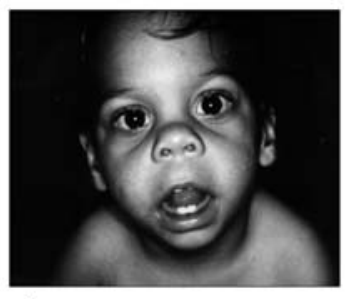

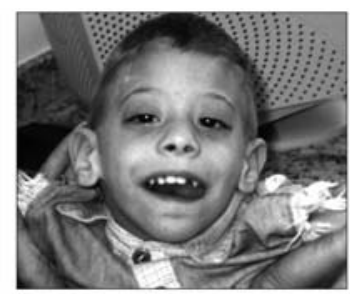

D



$\mathrm{H}$

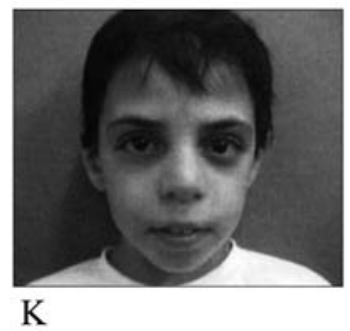

Figure 1 - Facial appearance of our confirmed cases of Smith-Lemli-Opitz syndrome (SLOS): (A) patient 1, (B) patient 2, (C) patient 3, (D) patient 4, (E) patient $5,(\mathrm{~F})$ patient $6,(\mathrm{G})$ patient $7,(\mathrm{H})$ patient $8,(\mathrm{I})$ patient $9,(\mathrm{~J})$ patient $10,(\mathrm{~K})$ patient 11. 
erature. The frequencies of signs/symptoms pertinent to the diagnosis of SLOS were calculated from literature reports, using two different estimation methods (Pardono et al., 2003). Estimate 1 was obtained using the formula $\mathrm{P} /(\mathrm{P}+\mathrm{A}+\mathrm{N})$, where $\mathrm{P}$ is the number of cases in which the finding was present, $\mathrm{A}$ is the number of cases in which it was absent, and $\mathrm{N}$ is the number of cases in which it was not mentioned. In estimate 1, it is hypothesized that, whenever the anomaly is not mentioned in a reference paper, it is absent. Estimate 2 was obtained using the formula $\mathrm{P} /(\mathrm{P}+\mathrm{A})$; when the finding is not mentioned, it is assumed that is was not searched for by the authors. The true value of the estimate is obviously an unknown quantity, but its upper and lower limits are given by estimates 1 and 2, respectively. A

Table 1 - Estimated frequencies of the signs/symptoms found in SLOS patients (literature and present study).

\begin{tabular}{|c|c|c|c|c|c|c|c|c|c|}
\hline \multirow[t]{3}{*}{ Signal/symptom } & \multicolumn{9}{|c|}{ SLOS patients } \\
\hline & \multicolumn{3}{|c|}{ Literature $(n=34)^{*}$} & \multicolumn{3}{|c|}{ Present sample } & \multicolumn{3}{|c|}{ Combined sample } \\
\hline & Est.1 & Est.2 & Comb. & Est.1 & Est.2 & Comb. & Est.1 & Est.2 & Comb. Est \\
\hline Microcephaly & $34 / 34$ & $34 / 34$ & 1.00 & $11 / 11$ & $11 / 11$ & 1.00 & $45 / 45$ & $45 / 45$ & 1.00 \\
\hline Prominent occipitus & $8 / 34$ & $8 / 14$ & 0.31 & - & - & - & - & - & - \\
\hline High forehead & $22 / 34$ & $22 / 24$ & 0.83 & $4 / 11$ & $4 / 11$ & 0.36 & $26 / 45$ & $26 / 35$ & 0.66 \\
\hline Large ears & $13 / 34$ & $13 / 13$ & - & $6 / 11$ & $6 / 11$ & 0.55 & $19 / 45$ & $19 / 24$ & 0.59 \\
\hline Low-set ears & $16 / 34$ & $16 / 31$ & 0.49 & - & - & - & - & - & - \\
\hline Rotated ears & $11 / 34$ & $11 / 16$ & 0.44 & $8 / 11$ & $8 / 11$ & 0.73 & $19 / 45$ & $19 / 27$ & 0.54 \\
\hline Hypertelorism & $6 / 34$ & $6 / 17$ & 0.22 & - & - & - & - & - & - \\
\hline Epicanthic folds & $23 / 34$ & $23 / 26$ & 0.81 & $6 / 11$ & $6 / 11$ & 0.55 & $29 / 45$ & $29 / 37$ & 0.72 \\
\hline Ptosis & $23 / 34$ & $23 / 27$ & 0.78 & $10 / 11$ & $10 / 11$ & 0.91 & $33 / 45$ & $33 / 38$ & 0.81 \\
\hline Strabismus & $9 / 34$ & $9 / 16$ & 0.35 & $5 / 11$ & $5 / 11$ & 0.45 & $14 / 45$ & $14 / 27$ & 0.38 \\
\hline Cataract & $2 / 34$ & $2 / 11$ & 0.07 & $2 / 11$ & $2 / 11$ & 0.18 & $4 / 45$ & $4 / 22$ & 0.11 \\
\hline Medial hypoplastic eyebrows & - & - & - & $8 / 11$ & $8 / 11$ & 0.73 & - & - & - \\
\hline Anteverted nostrils & $28 / 34$ & $28 / 34$ & 0.82 & $10 / 11$ & $10 / 11$ & 0.91 & $38 / 45$ & $38 / 45$ & 0.84 \\
\hline Narrow nasal bridge & $12 / 34$ & $12 / 13$ & 0.67 & - & - & - & - & - & - \\
\hline Flattened nose & - & - & - & $9 / 11$ & $9 / 11$ & 0.82 & - & - & - \\
\hline Long filtrum & - & - & - & $5 / 11$ & $5 / 11$ & 0.45 & - & - & - \\
\hline Micrognathia & $20 / 34$ & $20 / 22$ & 0.80 & $9 / 11$ & $9 / 11$ & 0.82 & $29 / 45$ & $29 / 33$ & 0.79 \\
\hline Bifid uvula & $6 / 34$ & $6 / 13$ & 0.23 & - & - & - & - & - & - \\
\hline Cleft palate & $9 / 34$ & $9 / 34$ & 0.26 & $4 / 11$ & $4 / 11$ & 0.36 & $13 / 45$ & $13 / 45$ & 0.29 \\
\hline High palate & - & - & - & $6 / 11$ & $6 / 11$ & 0.55 & - & - & - \\
\hline Tented upper lip & - & - & - & $10 / 11$ & $10 / 11$ & 0.91 & - & - & - \\
\hline Short neck & $18 / 34$ & $18 / 21$ & 0.71 & $7 / 11$ & $7 / 11$ & 0.64 & $25 / 45$ & $25 / 32$ & 0.67 \\
\hline Polydactyly & $7 / 34$ & $7 / 34$ & 0.21 & - & - & - & - & - & - \\
\hline Simian crease & $20 / 34$ & $20 / 34$ & 0.59 & $3 / 11$ & $3 / 11$ & 0.27 & $23 / 45$ & $23 / 45$ & 0.51 \\
\hline Toe syndactyly $(2 / 3)$ & $32 / 34$ & $32 / 34$ & 0.94 & $11 / 11$ & $11 / 11$ & 1.00 & $43 / 45$ & $43 / 45$ & 0.96 \\
\hline Toe polydactyly & $2 / 34$ & $2 / 21$ & 0.07 & - & - & - & - & - & - \\
\hline Club foot & $9 / 34$ & $9 / 13$ & 0.38 & - & - & - & - & - & - \\
\hline Cryptorchidism & $13 / 22$ & $13 / 22$ & 0.59 & $2 / 6$ & $2 / 6$ & 0.33 & $15 / 28$ & $15 / 28$ & 0.54 \\
\hline Hypospadias & $10 / 22$ & $10 / 22$ & 0.45 & $3 / 6$ & $3 / 5$ & 0.50 & $13 / 28$ & $13 / 28$ & 0.4 \\
\hline Ambiguous genitalia & - & - & - & $3 / 6$ & $3 / 6$ & 0.50 & - & - & - \\
\hline Muscular hypotrophy & $8 / 34$ & $8 / 34$ & 0.24 & $7 / 11$ & $7 / 11$ & 0.64 & $15 / 45$ & $15 / 45$ & 0.33 \\
\hline Cardiac anomalies & $4 / 34$ & $4 / 08$ & 0.15 & - & - & - & - & - & - \\
\hline Piloric stenosis & $6 / 34$ & $6 / 33$ & 0.18 & - & - & - & - & - & - \\
\hline Feeding difficulties & $16 / 34$ & $16 / 21$ & 0.60 & - & - & - & - & - & - \\
\hline $\begin{array}{l}\text { Neuropsychomotor } \\
\text { development delay }\end{array}$ & $20 / 34$ & $20 / 21$ & 0.87 & $10 / 11$ & $10 / 11$ & 0.91 & $30 / 45$ & $30 / 32$ & 0.86 \\
\hline Growth retardation & $7 / 34$ & $7 / 34$ & 0.27 & - & - & - & - & - & - \\
\hline Mental retardation & $34 / 34$ & $34 / 34$ & 1.00 & $10 / 11$ & $10 / 11$ & 0.91 & $44 / 45$ & $44 / 45$ & 0.98 \\
\hline
\end{tabular}

*Smith, Lemli and Opitz, 1964; Wallace et al., 1994; Comier-Daire et al., 1996; Guzzeta et al., 1996; Krajewska-Walasek et al., 1999. Combined sample $=$ literature + present study. 
combined estimate may be obtained by weighing estimates 1 and 2 (Est1 and Est2) by the reciprocals of their respective binomial variances (Var1 and Var2): comb. est. $=($ Est1/Var1 + Est2/Var2)/ (1/Var1+1/Var2). Identical methodology was applied to three different conditions that should be considered in the differential diagnosis of SLOS: alpha-thalassemia/mental retardation syndrome (MIM 141750), Opitz (G/BBB) syndrome (MIM300000), and Aarskog syndrome (MIM 305400) (Grier et al., 1983; Cappa et al., 1987; Fryns et al., 1992; Guion-De-Almeida and Richieri Costa, 1992; Mc Donald et al., 1993; Teebi et al., 1993; Fernandez et al., 1994; Gibbons et al., 1995; Reardon et al., 1995). The estimates thus obtained are shown in Table 2. These values allow the calculation of the probabilities favoring the diagnosis of SLOS in relation to each one of the other three conditions. If no information about a given trait is available, the probability rate (likelihood) takes the indifferent value 1 . To exemplify the use of the table data, let us suppose that in a given patient suspected of having SLOS or Opitz syndrome, only the first four features shown in the table were searched and that the first three features were present and the last one was absent. In this case, the likelihood favoring the diagnosis of SLOS is the product: $95 / 5 \times 66 / 30 \times 54 / 80 \times 78 / 5=440.754$, that is, given this set of anomalies, the probabilities favoring both diagnoses are in the ratio of 440.754: 1; therefore, the probability of SLOS diagnosis is obtained by normalizing 440.754 and $1: \mathrm{P} 1=440.754 /(440.754+1)=440.754$ $/ 441.754=0.9977$.

\section{Results}

The clinical diagnosis of SLOS was confirmed biochemically by abnormally high levels of 7-dehydrocholesterol and low plasma cholesterol levels in 11 of the 30 patients studied (Table 3 ). In these 11 patients, cholesterol and 7-dehydrocholesterol levels ranged from 50 to $143 \mathrm{mg} / \mathrm{dL}$ and 1.56 to $28.81 \mathrm{mg} / \mathrm{dL}$, respectively. The remaining 19 patients had 7-dehydrocholesterol levels that could not be quantified and normal cholesterol levels (94-221 mg/dL).

The clinical traits observed in our sample of $30 \mathrm{pa}-$ tients are summarized in Table 4. Among the eleven patients with positive biochemical results, only one patient presented apparently normal development (case 11). Of the remaining 10, seven could not walk or talk (cases 1, 2, 4, 5,

Table 2 - Reported frequencies of signs and symptoms in SLOS, Opitz syndrome, Aarskog syndrome and alpha-thalassemia/mental retardation syndrome. Whenever the frequency of a given feature (with the exception of polydactyly) was not increased in a given syndrome, a frequency of $5 \%$ was assigned to it.

\begin{tabular}{|c|c|c|c|c|}
\hline \multirow[t]{2}{*}{ Signal/symptom } & SLO & Opitz & Aarskog & alpha-thal. \\
\hline & PRES: ABS & PRES: ABS & PRES: ABS & PRES: ABS \\
\hline Microcephaly & $95: 5$ & 5: 95 & 5: 95 & 5: 95 \\
\hline High palate & 66: 34 & 30: 70 & 34: 66 & 5: 95 \\
\hline Rotated ears & $54: 46$ & $80: 20$ & 5: 95 & $65: 35$ \\
\hline Hypertelorism & $22: 78$ & $95: 5$ & 95: 5 & 5: 95 \\
\hline Ptosis & $81: 19$ & 10: 90 & $44: 56$ & 5: 95 \\
\hline Strabismus & 38: 62 & $15: 85$ & 5: 95 & 5: 95 \\
\hline Anteverted nostrils & $84: 16$ & $45: 55$ & $75: 25$ & 88: 12 \\
\hline Micrognathia & 79: 21 & $30: 70$ & $67: 33$ & 5: 95 \\
\hline Short neck & $67: 33$ & 5: 95 & 5: 95 & 5: 95 \\
\hline Syndactyly & $96: 4$ & 5: 95 & 21: 79 & 5: 95 \\
\hline Polydactyly & 7: 93 & 1: 99 & 1: 99 & 1: 99 \\
\hline Cryptorchidism & 54: 46 & $35: 65$ & 5: 95 & $61: 39$ \\
\hline Hypospadias & 46: 54 & 45: 55 & 5: 95 & 12: 88 \\
\hline Club feet & $38: 62$ & 5: 95 & 5: 95 & 59: 41 \\
\hline Hypotrophic musculature & 33: 67 & 5: 95 & 5: 95 & 5: 95 \\
\hline Mental retardation & 98: 2 & 5: 95 & $25: 75$ & 92: 8 \\
\hline Neuropsychomotor development delay & $86: 14$ & 5: 95 & 5: 95 & 5: 95 \\
\hline Cardiac anomalies & 5: 95 & $65: 35$ & 5: 95 & 12: 88 \\
\hline Central nervous system defects & 5: 95 & $80: 20$ & 5: 95 & 5: 95 \\
\hline Clinodactyly & 5: 95 & 5: 95 & 50: 50 & $35: 65$ \\
\hline Kidney defects & 5: 95 & 5: 95 & 5: 95 & 18: 82 \\
\hline "Shawl"scrotum & 5: 95 & 5: 95 & 87: 13 & 5: 95 \\
\hline
\end{tabular}


7, 9 and 10), and three started walking and talking after 3 years of age (cases 3, 6 and 8). All the 11 patients with positive biochemical results and 16 of the remaining 19 patients were cytogenetically evaluated and no chromosomal anomalies were detected in any of them.
Table 3 shows the estimated frequencies of the traits found in patients with SLOS (cases from the literature and from the present study). Combining the data of our 11 patients with biochemically confirmed SLOS with those from the literature, at least $2 / 3$ of them have microcephaly, epi-

Table 3 - 7-DHC and cholesterol plasma levels $(\mathrm{mg} / \mathrm{dL})$ in patients suspected of having SLOS $(\mathrm{n}=30)$.

\begin{tabular}{|c|c|c|c|c|c|c|c|c|c|c|c|c|}
\hline \multirow{2}{*}{$\begin{array}{l}\text { Biochemical } \\
\text { tests }\end{array}$} & \multicolumn{12}{|c|}{ Patients } \\
\hline & 1 & 2 & 3 & 4 & 5 & 6 & 7 & 8 & 9 & 10 & 11 & $\begin{array}{c}\text { Other cases } \\
\mathrm{n}=19\end{array}$ \\
\hline Cholesterol & 126 & 68 & 97 & 80 & 50 & 83 & 76 & 75 & 65 & 71 & 143 & $94-221$ \\
\hline 7-DHC & 11.6 & 13.95 & 21.6 & 14.1 & 11 & 4.35 & 28.81 & 11.3 & 8.65 & 6.35 & 1.59 & - \\
\hline
\end{tabular}

Table 4 - Clinical findings in 30 patients suspected of having the Smith-Lemli-Opitz syndrome.

\begin{tabular}{|c|c|c|c|c|c|c|c|c|c|c|c|c|c|c|c|c|c|c|c|c|c|c|c|c|c|c|c|c|c|c|}
\hline \multirow[t]{2}{*}{ Clinical features } & \multicolumn{30}{|c|}{ Patients } \\
\hline & 1 & 2 & 3 & 4 & 5 & 6 & 7 & 8 & 9 & 10 & 11 & 12 & 13 & 14 & 15 & 16 & 17 & 18 & 19 & 20 & 21 & 22 & 23 & 24 & 25 & 26 & 27 & 28 & 29 & 30 \\
\hline Microcephaly & + & + & + & + & + & + & + & + & + & + & + & & & & + & + & & & + & + & & + & & + & & & & + & + & \\
\hline High forehead & & + & & & & & + & & & + & + & & + & & & + & + & & & + & + & + & + & + & & & & + & + & + \\
\hline Rotated ears & & & & & & & & & & & + & + & & & & & + & + & + & + & + & + & & & & + & & & + & \\
\hline Low-set ears & & & & & & & & & & & & & & & & & & & & & & & & & & + & & + & & + \\
\hline Hypertelorism & + & & + & + & & + & + & & & + & & + & & & & & & & & & & & + & & & + & & & & \\
\hline Ptosis & + & + & + & + & + & + & + & + & + & + & & + & & + & + & + & & & & & & + & + & & & & & & & \\
\hline Strabismus & + & & + & + & + & & + & & & & & & & & + & & & & + & & + & + & & & & + & & & & + \\
\hline Cataract & & & & & + & + & & & & & & & & & & & & & & & & & & & & & & & & \\
\hline $\begin{array}{l}\text { Medial hypoplastic } \\
\text { eyebrows }\end{array}$ & + & + & + & + & + & & + & & + & + & & & & & & + & & & & & & & & & & & & & & \\
\hline Anteverted nostrils & + & + & + & + & + & & + & + & + & + & + & + & & & + & + & + & & + & + & & & + & & & + & & & + & + \\
\hline Micrognathia & + & + & + & + & + & + & + & & & + & + & & & + & + & + & & + & & + & & + & + & & & & & & & \\
\hline Tented upper lip & + & + & + & + & + & + & + & & + & + & + & + & & & + & + & + & & & + & & & & & & + & & & & + \\
\hline Macroglossia & & & & & & & & & & & & + & & & & & & & & & & & & & & & & & & \\
\hline High palate & & & + & + & & + & & + & + & + & & + & + & + & & & & + & + & + & & + & + & + & + & & + & + & & + \\
\hline Cleft palate & & & & + & + & + & & + & & & & & & & & & & & & & & & & & & & & & & \\
\hline Short neck & + & + & & + & + & + & + & + & & & & + & & & + & + & & & & + & + & & + & & & & & & & + \\
\hline Polydactyly & & & & & & & & & & & & & + & & & & & & & & & & & & & & & & & \\
\hline Clinodactyly & & & & & + & + & & & & & & + & & & & & & + & & & & & + & & + & + & & & & \\
\hline Club feet & & & & & & & & & & & & + & + & & + & & & & & & & + & & + & & & + & & + & \\
\hline Toe syndactyly $(2 / 3)$ & + & + & + & + & + & + & + & + & + & + & + & & & & & + & + & & + & & & & + & + & & & & + & & \\
\hline Toe polydactyly & & & & & & & & & & & & + & & & & & & & & & & & & & & & & & & \\
\hline Ambiguous genitalia & + & & & & & & & & & & & & & & & & + & + & & & & & & & & & + & & & \\
\hline Small penis & & & & & & & & & & & & & & & & & & & & & & & & & & & + & + & & \\
\hline Cryptorchidism & & + & & & & & + & & & & + & & & & & + & & & & + & + & & & & + & + & & + & + & \\
\hline Hypospadias & & + & & + & & & & + & & & + & & & & & + & & & & & + & & + & & + & + & & & & \\
\hline Shawl scrotum & & & & & & & & & & & & & & & & & & & & & & & & & & + & & & & \\
\hline Exstrophy of cloaca & & & & & & & & & & & & & + & & & & & & & & & & & & & & & & & \\
\hline Imperforate anus & & & & & & & & & & & & & + & & & & & & & & & & & & & & & & & \\
\hline Muscular hypotrophy & + & + & + & + & & + & & & + & + & & + & & + & + & + & & + & & + & & + & + & + & & + & & & & + \\
\hline Mental retardation & + & + & + & + & + & + & + & + & + & + & & + & & + & + & + & & & + & + & + & + & + & & + & + & + & & + & + \\
\hline $\begin{array}{l}\text { Neuropsychomotor } \\
\text { development delay }\end{array}$ & + & + & + & + & + & + & + & + & + & + & & + & + & + & + & + & & & + & + & + & + & + & & + & + & + & & + & + \\
\hline Growth retardation & & + & & & & & & & & & & + & & + & + & & & & & & & & & & + & + & & & & \\
\hline Cardiac anomalies & & & & & & & & & & & & & & & & & & & & + & & & & & & & & & & + \\
\hline Dandy Walker anomaly & & & & & & & & & & & & & & & & & & & & & & & & & & & & & & + \\
\hline
\end{tabular}


canthic folds, anteverted nostrils, micrognathia, short neck, cutaneous foot syndactyly, and delayed neuropsychomotor development or mental retardation. Other important findings in more than $2 / 3$ of our patients (Table 1 ) were: tented upper lip (10/11), medial hypoplastic eyebrows (8/11), hypotrophic musculature $(8 / 11)$, and incompletely rotated ears $(8 / 11)$. All the boys exhibited some kind of genital alteration $(6 / 6)$.

Discriminant analysis showed that only $3 / 30$ of our patients presented a low probability favoring the diagnosis of SLOS in relation to the other three conditions, Opitz (G/BBB) syndrome, Aarskog syndrome and alpha-thalassemia/mental retardation (Table 5).

Table 5 - Probability figures favoring the hypothesis of SLOS in each of our 30 patients.

\begin{tabular}{|c|c|c|c|}
\hline \multirow[t]{2}{*}{ Patients } & \multicolumn{3}{|c|}{ Probability figures favoring the diagnosis of SLOS relative to } \\
\hline & $\begin{array}{c}\text { Opitz } \\
\text { syndrome } \\
\text { P1 }\end{array}$ & $\begin{array}{c}\text { Aarskog } \\
\text { syndrome } \\
\text { P2 }\end{array}$ & $\begin{array}{c}\text { Alpha-thalassemia/ } \\
\text { mental retardation } \\
\text { P3 }\end{array}$ \\
\hline $1^{*}$ & 1.0000 & 1.0000 & 1.0000 \\
\hline $2^{*}$ & 1.0000 & 1.0000 & 1.0000 \\
\hline $3^{*}$ & 1.0000 & 1.0000 & 1.0000 \\
\hline $4^{*}$ & 1.0000 & 1.0000 & 1.0000 \\
\hline $5^{*}$ & 1.0000 & 1.0000 & 1.0000 \\
\hline $6^{*}$ & 1.0000 & 1.0000 & 1.0000 \\
\hline $7 *$ & 1.0000 & 1.0000 & 1.0000 \\
\hline $8^{*}$ & 1.0000 & 1.0000 & 1.0000 \\
\hline $9 *$ & 1.0000 & 1.0000 & 1.0000 \\
\hline $10^{*}$ & 1.0000 & 1.0000 & 1.0000 \\
\hline $11 *$ & 0.9996 & 1.0000 & 0.9999 \\
\hline 12 & 0.9999 & 0.9985 & 0.8941 \\
\hline 13 & 0.3385 & 0.0554 & 0.0766 \\
\hline 14 & 0.9991 & 0.9252 & 0.9541 \\
\hline 15 & 1.0000 & 1.0000 & 1.0000 \\
\hline 16 & 0.0084 & 0.2072 & 0.0042 \\
\hline 17 & 1.0000 & 1.0000 & 1.0000 \\
\hline 18 & 0.0001 & 0.0000 & 0.0000 \\
\hline 19 & 1.0000 & 1.0000 & 0.9959 \\
\hline 20 & 1.0000 & 1.0000 & 0.9999 \\
\hline 21 & 0.9767 & 0.9953 & 0.7442 \\
\hline 22 & 1.0000 & 1.0000 & 1.0000 \\
\hline 23 & 1.0000 & 1.0000 & 1.0000 \\
\hline 24 & 1.0000 & 0.9990 & 1.0000 \\
\hline 25 & 0.9961 & 0.9903 & 0.9492 \\
\hline 26 & 0.0000 & 0.0000 & 0.0001 \\
\hline 27 & 0.9992 & 0.9744 & 0.0512 \\
\hline 28 & 0.7788 & 1.0000 & 0.3485 \\
\hline 29 & 0.998 & 1.0000 & 0.3485 \\
\hline 30 & 0.8216 & 0.9997 & 0.9427 \\
\hline
\end{tabular}

*Patients confirmed biochemically.

\section{Discussion}

Eleven of the 30 patients suspected of having SLOS exhibited increased levels of 7-dehydrocholesterol. In the literature, studies including controls and SLOS carriers have shown that 7-DHC and cholesterol levels were normal in all controls, whereas in patients with SLOS the 7-DHC levels were always increased; cholesterol levels were normal only in 10\% of patients (Axelson, 1991; Nowaczyk et al., 1999). These and other similar studies in the literature, however, do not clearly state the clinical inclusion criteria used in the diagnosis of SLOS in cases which are not completely typical.

The plasma 7-DHC levels found in our 11 patients by UV spectrophotometry were higher than $1 \mathrm{mg} / \mathrm{dL}$ of plasma, a result consistent with that found by Honda et al. (1997).

The clinical diagnosis of SLOS is hindered by the fact that none of its signs or symptoms is pathognomonic. Despite this difficulty, the association of mental retardation with genital anomalies in males and a typical facial appearance seems to be the most important clinical indicator of SLOS (Guzzeta et al., 1996; Cuniff et al., 1997; Ryan et al., 1998; Krajewska-Wallasek et al., 1999). That is exactly what we observed among our biochemically confirmed patients.

Thirty-four cases of the literature were reviewed and their clinical findings were compared with those of our biochemically confirmed SLOS patients. The most frequent findings in our sample were: mental retardation (10/11), microcephaly (11/11), delayed neuropsychomotor development $(10 / 11)$, and syndactyly of the $2^{\text {nd }}$ and $3^{\text {rd }}$ toes (11/11). The six male patients had genital anomalies. A typical face (with incompletely rotated ears, palpebral ptosis, anteverted nostrils, flattened nasal base, and micrognathia) is easily recognized in all 11 patients. According to the review by Kelley and Hennekan (2000) including 164 individuals with SLOS, the anomalies present in over $50 \%$ of the biochemically confirmed cases are: syndactyly of the $2^{\text {nd }} / 3^{\text {rd }}$ toes $(97 \%)$, mental retardation $(95 \%)$, microcephaly (84\%), anteverted nostrils (78\%), and palpebral ptosis $(70 \%)$. The corresponding frequencies observed in the present study, therefore, do not differ from those observed in a larger number of affected individuals.

Another facial anomaly commonly found among our SLOS patients, but not frequently reported in the literature (though usually observed in photos), was a tented upper lip (10/10), a characteristic described by Neri and Opitz (1999) as "elongated upper lip" and by Kelley (2000) as "large mouth, which, combined with frequent micrognathia, gives a distinctive appearance". Another facial trait that seems not to have been described in the literature so far, but was frequently observed in our patients (8/11), is the presence of medial hypoplastic eyebrows.

The comparison between the frequencies of the most significant SLOS signs and symptoms observed in our pa- 
tients and those observed in three other entities, by using a simplified discriminant analysis technique, led us to conclude that all 11 patients with positive biochemical results and 16 of the 19 with negative results had a high probability of having SLOS. This fact suggests that the latter group of patients should be investigated molecularly.

Recent studies have indicated that the malformations associated with SLOS can be traced to the role cholesterol plays in normal embryonic development. Most malformations seen in SLOS are likely to be related with a role of cholesterol in the hedgehog signal transduction pathway (Roux et al., 2000; Waterham and Wanders, 2000). Hedgehog $(\mathrm{Hh})$ proteins form a family of embryonic signaling molecules, which are important for patterning in embryos. In humans, these proteins are called Sonic hedgehog (SHH), Desert hedgehog (DHH), and Indian hedgehog (IHH). The covalent addition of cholesterol to $\mathrm{SHH}$ is essential for its autoprocessing. SHH participates in the development patterning of the ventral forebrain, neural tube and limbs, among other structures. A similar process may be responsible for abnormal responses to $\mathrm{DHH}$ and $\mathrm{IHH}$ in the development of the genital tract and skeleton, respectively (Porter et al., 1996; Hammerschmidt et al., 1997; Tabin and McMahon, 1997).

Based on the discovery that the impaired function of development proteins (Hh) may explain a number of malformations present in SLOS, our hypothesis, to be tested in future studies, is that some of the patients who show typical malformations of SLOS but negative biochemical results have a defect, not in the DHCR7 gene (that codifies $\Delta^{7}$-sterol reductase), but in a developmental gene that codifies for Hh proteins.

\section{Acknowledgments}

We thank Raquel de Camargo (SAG, UNESP, Botucatu, SP), Agnes Fett-Conte (FAMERP, São José do Rio Preto, SP), Chong Ae Kim (IC, USP, São Paulo, SP), Dafne Horowitz, Juan Llerena and Cecília Oliveira (CERES and IFF/FIOCRUZ, Rio de Janeiro, RJ), Eugênia Valadares (FM, UFMG, Belo Horizonte, MG), Antônio Richieri Costa (HRAC, USP, Bauru, SP), Lidiane Rosso and Beatriz Versiani (FM, USP, Ribeirão Preto, SP), Antonia Paula de Faria (FCM, UNICAMP, Campinas, SP), Têmis Félix (HCPA, UFRGS, Porto Alegre, RS) and Carlos Speck Martins (Hospital SARAH, Brasília, DF) for allowing access to patients and their medical records. Financial support: CAPES, Fundação Lucentis and FCFAR.

\section{References}

Allain CC, Poon LS, Chan CSG, Richmond W and Fu P (1974) Enzymatic determination of total serum cholesterol. Clin Chem 20:470.

Axelson M (1991) Occurrence of isomeric dehydrocholesterols in human plasma. J Lipid Res 32:1441-1448.
Cappa M, Borelli P, Marini R and Neri G (1987) The Opitz syndrome: A new designation for the clinically indistinguishable BBB and G syndrome. Am J Med Genet 28:303-309.

Cormier-Daire V, Wolf C, Munnich A, Le Merrer M, Nivelon A, Bonneau D, Journel H, Fellmann F, Chevy F and Roux C (1996) Abnormal cholesterol biosynthesis in the SmithLemli-Opitz and the lethal acrodysgenital syndromes. Europ J Pediatr 155:656-659.

Correa-Cerro LS and Porter FD (2005) 3 $\beta$-hydroxysterol $\Delta 7$-reductase and the Smith-Lemli-Opitz syndrome. Mol Genet Metabolism 84:112-126.

Cunniff C, Kratz LE, Moser A, Natowicz MR and Kelley RI (1997) Clinical and biochemical spectrum of patients with RSH/Smith-Lemli-Opitz syndrome and abnormal cholesterol metabolism. Am J Med Genet 68:263-269.

Curry CJR, Carey JC, Holland JS, Chopra D, Fineman R, Golabi M, Sherman S, Pagon RA, Allanson J, Shulman S, Barr M, McGravey V, Dabiri C, Schimke N, Ives E and Hall BD (1987) Smith-Lemli-Opitz syndrome type II: Multiple congenital anomalies with male pseudohermaphroditism and frequent early lethality. Am J Med Genet 26:45-57.

Evans T, Poh E, Webb C, Wainwright B, Wicking C, Glass I, Carey W and Fietz M (2001) Novel mutations in the delta-7-dehydrocholesterol reductase gene in an Australian patient with Smith-Lemli-Opitz syndrome. Am J Med Genet 103:223-225.

Fernandez I, Tsukara M, Mito H, Yoshi A, Uchida M, Matsuo K and Kojii T (1994) Congenital heart defects in Aarskog syndrome. Am J Med Genet 50:318-322.

Fitzky BU, Witsch-Baumgartner M, Erdel M, Lee JN, Paik Y, Glossmann H, Utermann G and Moebius FF (1998) Mutations in the $\Delta 7$-sterol reductase gene in patients with the Smith-Lemli-Opitz syndrome. Proc Natl Acad Sci USA 95:8181-8186.

Fryns JP, Delooz J and Vandenbergh H (1992) Posterior scalp defects in Opitz syndrome: Another symptom related to a defect in middle development. Clin Genet 42:314-316.

Gibbons RJ, Brueton L, Buckle VJ, Burn VJ, Clayton-Smith J, Davison BCC, Gardner RJM, Homfray T, Kearney L, Kingston HM, Newbury-Ecob R, Porteous MEP, Wilkie AOM and Higgs DR (1995) Clinical end hematological aspects of the X-linked $\alpha$-thalassemia/mental retardation syndrome (ATR-X). Am J Med Genet 59:288-299.

Grier RE, Farrington FH, Kendig R and Mamunes P (1983) Autosomal dominant inheritance of the Aarskog syndrome. Am J Med Genet 15:39-46.

Guion-De-Almeida ML and Richieri-Costa A (1992) Aarskog syndrome in a Brazilian boy born to consanguineous parents. Am J Med Genet 43:808-810.

Guzzetta V, De Fabiani E, Galli G, Colombo C, Corso G, Lecora M, Parenti G, Strisciuglio P and Andria G (1996) Clinical and biochemical screening for Smith-Lemli-Opitz syndrome. Acta Pediatric 85:937-942.

Haas D and Kelley RI (2001) Inherited disorders of cholesterol biosynthesis. Neuropediatr 32:113-122.

Hammerschmidt M, Brook A and McMahon AP (1997) The world according to hedgehog. Trends Genet 13:14-21.

Honda A, Batta AK, Salen G, Tint S, Chen T and Shefer S (1997) Screening for abnormal cholesterol biosynthesis in the Smith-Lemli-Opitz syndrome: Rapid determination of plas- 
ma 7-dehydrocolesterol by ultraviolet spectrometry. Am J Med Genet 68:288-293.

Irons M, Elias ER, Salen G, Tint GS and Batta AK (1993) Defective cholesterol biosynthesis in Smith-Lemli-Opitz syndrome. The Lancet 34:341.

Kelley RI (2000) Inborn errors of cholesterol biosynthesis. Adv Pediatr 47:1-29.

Kelley RI and Hennekam RCM (2000) The Smith-Lemli-Opitz syndrome. J Med Genet 37:321-335.

Krajewska-Walasek M, Gradowka W, Rysko J, Socha P, Chmielik J, Szaplyko W, Kasprzyk J, Górska B, Szreter M, Wolski J, Rysiewski H, Malunowicz EM, Gregorek H, Michalkiewicz J, Pietraszek E and Szplyko (1999) Further delineation of classical Smith-Lemli-Opitz syndrome phenotype at different patient ages: Clinical and biochemical studies. Clin Dysmorphol 8:29-40.

Lowry RB and Yong SL (1980) Borderline normal intelligence in the Smith-Lemli-Opitz (RSH) syndrome. Am J Med Genet 5:137-143.

McDonald RMM, Shafer BG, Tamayo M and Frías JL (1993) Brain magnetic resonance imaging findings in the Opitz syndrome: Extension of the spectrum of middle brain anomalies. Am J Med Genet 46:706.

Moebius FF, Fitzky BU, Lee JN, Paik YK and Glossmann H (1998) Molecular cloning and expression of the human delta-7-sterol reductase. Proc Nat Acad Sci 95:1899-1902.

Neri G and Opitz J (1999) Syndromal (and nonsyndromal) forms of male pseudohermaphroditism. Am J Med Genet 89:201209.

Nowaczyk MJM, McCaughey D, Whelan DT and Porter FD (2001) Incidence of Smith-Lemli-Opitz syndrome in Ontario, Canada. Am J Med Genet 102:18-20.

Nowaczyk MJM and Waye JS (2001) The Smith-Lemli-Opitz syndrome: A novel metabolic way of understanding developmental biology, embryogenesis, and dysmorphology. Clin Genet 59:375-386.

Nowaczyk MJM, Whelan DT, Heshka TW and Hill RE (1999) Smith-Lemli-Opitz syndrome: A treatable inherited error of metabolism causing mental retardation. CMAJ 27:163-170.

Pardono E, Bever Y, Ende J, Havrenne PC, Iughetti P, Maestrelli SRP, Costa OF, Richieri-Costa A, Frota-Pessoa O and Otto PA (2003) Waardenburg syndrome: Clinical differentiation between types I and II. Am J Med Genet 117A:223-235.

Porter JA, Young KE and Beachy PA (1996) Cholesterol modification of hedgehog signaling proteins in animal development. Science 274:255-259.

Porter FD (2000) RSH/Smith-Lemli-Opitz syndrome: A multiple congenital anomaly/mental retardation syndrome due to an inborn error of cholesterol biosynthesis. Mol Genet Metabol 71:167-174.

Reardon W, Gibons RJ, Winter RM and Baraitser M (1995) Male pseudohermaphroditism in sibs with the alpha-thalassemia/ mental retardation (ATR syndrome). Am J Med Genet 55:285.

Ryan AK, Bartlett K, Clayton P, Eaton S, Mills L, Donnai D, Winter RM and Burn J (1998) Smith-Lemli-Opitz syndrome: A variable clinical and biochemical phenotype. J Med Genet 35:558-565.
Roux C, Wolf C, Mulliez N, Gaoua W, Cormier V, Chevy F and Citadelle D (2000) Role of cholesterol in embryonic development. Am J Clin Nutr 71:1270-1279.

Scalco FB, Correa-Cerro LS, Wassif CA, Porter FD and MorretiFerreira D (2005) DHCR7 Mutations in Brazilian SmithLemli-Opitz Syndrome Patients. Am J Med Genet 136A:278-281.

Shefer S, Salen G, Batta AK, Honda A, Tint GS, Irons M, Elias ER, Chen TC and Holick MF (1995) Markedly inhibited 7-dehydrocholesterol- $\Delta^{7}$-reductase activity in liver microsomes from Smith-Lemli-Opitz homozygotes. J Clin Invest 96:1779-1785.

Smith DW, Lemli L and Opitz JM (1964) A newly recognized syndrome of multiple congenital anomalies. J Pediatr 64:210-217

Tabin CJ and McMahon AP (1997) Recent advances in hedgehog signaling. Trends Cell Biol 7:442-446.

Teebi AS, Rucquoi JK and Meyn MS (1993) Aarskog syndrome: Report of a family with review and discussion of nosology. Am J Med Genet 46:501-509.

Tint GS, Irons M, Elias ER, Batta AK, Frieden R, Chen TS and Salen G (1994) Defective cholesterol biosynthesis associated with the Smith-Lemli-Opitz syndrome. The New Engl J Med 330:107-113.

Wallace M, Zori RT, Alley T, Whidden E, Gray BA and Williams CA (1994) Smith-Lemli-Opitz syndrome in a female with a de novo, balanced translocation involving 7q32: Probable disruption of an SLOS gene. Am J Med Genet 50:368-374.

Wassif CA, Maslen C, Kachilele-Linjewile S, Lin D, Linck M, Connor W, Steiner RD and Porter FD (1998) Mutations in the human sterol $\Delta 7$-reductase gene at $11 \mathrm{q} 12-13$ cause Smith-Lemli-Opitz. Am J Hum Genet 63:55-62.

Waterham HR, Wijburg FA, Hennekam RCM, Vreken P, Poll-The BT, Dorlan L, Duran M, Jira PE, Smeitink JAM, Wevers RA and Waders RJA (1998) Smith-Lemli-Opitz syndrome is caused by mutations in the 7-dehydrocholesterol reductase gene. Am J Hum Genet 63:329-338.

Waterham HR and Wanders RJA (2000) Biochemical and genetic aspects of 7-dehydrocholesterol reductase and SmithLemli-Opitz syndrome. Biochim Biophys Acta 1529:340356.

Witsch-Baumgartner M, Fitzky BU, Ogorelkowa M, Kraft HG, Moebius FF, Glossmann H, Seedorf U, Gillessen-Kaesbach G, Hoffmann GF, Clayton P, Kelley RI and Utermann G (2000). Mutational spectrum in the $\Delta 7$-sterol reductase gene and genotype-phenotype correlation in 84 patients with Smith-Lemli-Opitz syndrome. Am J Med Genet 66:402412.

Yu H, Tint GS, Salen G and Patel SB (2000) Detection of a common mutation in the RSH or Smith-Lemli-Opitz syndrome by a PCR-RFLP assay: IVS8-1G $\rightarrow \mathrm{C}$ is found in over sixty percent of US propositi. Am J Med Genet 90:347-350.

\section{Internet Resources}

The URL for data presented here is as follows: Online Mendelian Inheritance in Man (OMIM), http://www.ncbi.nlm.nih. gov/OMIM.

Associate Editor: John M. Opitz 